Artikel Review

\title{
Pengaruh Absorpsi Kalsium oleh Vitamin D Pada Penderita Obesitas
}

\author{
Nabila Jemima Aji, Anna Fitriani* \\ Program Studi S1 Ilmu Gizi, Fakultas Ilmu-Ilmu Kesehatan, Universitas Muhammadiyah Prof. Dr. Hamka, Indonesia \\ *Corresponding author: annafitriani@uhamka.ac.id
}

\begin{abstract}
Background: Obesity continues to increase every year due to lifestyle changes that affect food intake and physical activity in everyone. In addition to being at risk for degenerative diseases, obese people are also at risk of developing bone diseases such as osteomalacia, osteopenia, and rickets. Obese people need stronger bone strength to support their bodies compared to people who have normal weight. To form stronger bones requires a high intake of calcium. Vitamin D plays a very important role in optimizing the absorption of calcium in the body. Objective: To determine the effect of calcium absorption by vitamin D on obesity. Results: Obesity affects the bioavailability of vitamin D in the body due to high adipose tissue and low exposure to sunlight. Low levels of vitamin $D$ in the body will reduce calcium absorption. Conclusion: Vitamin D levels in obese patients directly affect calcium absorption in the body. However, further and in-depth research is needed to prove that obese people have direct risk factors for bone diseases such as osteomalacia, rickets, and osteoporosis due to low absorption of calcium from the influence of low levels of vitamin $D$ in the body.
\end{abstract}

Keywords: calcium, obesity, vitamin d

\begin{abstract}
ABSTRAK
Latar belakang: Obesitas terus mengalami peningkatan setiap tahunnya akibat perubahan gaya hidup sehingga mempengaruhi asupan makan dan aktivitas fisik pada setiap orang. Selain berisiko terkena penyakit degeneratif, penderita obesitas juga berisiko terkena penyakit pada tulang seperti, osteomalasia, osteopenia, dan riketsia. Penderita obesitas membutuhkan kekuatan tulang yang lebih kuat untuk menopang tubuhnya dibandingkan dengan orang yang memilki berat badan normal. Untuk membentuk tulang yang lebih kuat dibutuhkan asupan kalsium yang tinggi. Vitamin D sangat berperan untuk mengoptimalkan absorbsi kalsium dalam tubuh. Tujuan: Untuk mengetahui pengaruh absorbsi kalsium oleh vitamin D pada obesitas. Hasil: Obesitas mempengaruhi biovailabilitas vitamin D dalam tubuh akibat tingginya jaringan adiposa dan rendahnya paparan terhadap sinar matahari. Rendahnya kadar vitamin D dalam tubuh akan menurunkan absorbsi kalsium. Simpulan: Kadar vitamin D pada penderita obesitas memang secara langsung mempengaruhi absorbsi kalsium dalam tubuh. Namun penelitian lebih lanjut dan mendalam diperlukan untuk membuktikan bahwa penderita obesitas memiliki faktor risiko langsung terhadap penyakit pada tulang seperti osteomalasia, riketsia, dan osteoporosis akibat rendahnya absorbsi kalsium dari pengaruh rendahnya kadar vitamin D dalam tubuh.
\end{abstract}

Kata kunci: kalsium, obesitas, vitamin d 


\section{PENDAHULUAN}

Obesitas termasuk salah satu masalah kesehatan yang terus meningkat setiap tahunnya. Peningkatan kejadian obesitas tidak hanya terjadi di negara maju, namun juga di negara berkembang $(1,2)$. Diperkirakan angka kejadian obesitas di negara berkembang akan melampaui angka kejadian obesitas di negara maju akibat adanya transisi ekonomi (1).

Prevalensi obesitas di Indonesia semakin meningkat dari tahun ke tahun. Menurut Hasil Riset Kesehatan Dasar (RISKESDAS) tahun 2018 prevalensi penderita obesitas usia $>18$ tahun di Indonesia mengalami peningkatan yang cukup pesat yaitu mencapai $21,8 \%$ jika dibandingkan dengan tahun 2013 yang hanya sebesar 14,8\% (3). Semakin tinggi angka prevalensi obesitas, semakin tinggi pula angka morbiditas dan mortalitas di Indonesia (4). Obesitas juga banyak terjadi pada anak-anak akibat berkembangnya mitos anak yang gemuk merupakan simbol dari anak yang sehat. Anak yang obesitas cenderung tetap obesitas hingga dewasa dan berisiko terkena penyakit tidak menular $(2,5)$.

Seseorang yang obesitas mengalami penumpukan jaringan lemak dan berisiko dengan berbagai penyakit tidak menular, seperti penyakit jantung koroner, hipertensi, diabetes mellitus, serta stroke (6-8). Selain itu, penderita obesitas juga rentan terkena penyakit yang menyerang tulang seperti, osteomalasia, osteopenia, dan riketsia akibat beratnya beban pada tulang untuk menopang tubuh $(6,7)$. Oleh karena itu, orang yang obesitas membutuhkan kekuatan tulang yang lebih besar dibandingkan dengan orang yang memilki berat badan ideal (7).

Pada penderita obesitas, tulang yang lebih kuat dibutuhkan untuk menopang tubuh dalam melakukan aktivitas seharihari. Pembentukan tulang yang kuat membutuhkan asupan kalsium yang lebih banyak. Kalsium adalah salah satu mineral yang penting bagi tubuh, antara lain untuk metabolisme tubuh, penghubung antar syaraf, kerja jantung, pergerakan otot, dan terutama bagi pembentukan tulang dan gigi (9).

Selain kalsium, vitamin D juga sangat berperan untuk mengoptimalkan pembentukan kekuatan tulang. Vitamin D berperan sebagai pengatur metabolisme kadar kalsium dalam tubuh (6). Menurut beberapa penelitian, penderita obesitas memiliki kadar vitamin D yang lebih rendah dibandingkan dengan yang tidak obesitas, karena kebanyakan serum vitamin D tersebut disimpan ke dalam jaringan lemak (10-12). Selain itu, orang obesitas yang umumnya kurang menyukai aktivitas di luar rumah untuk mendapatkan sinar matahari yang juga bisa menyebabkan biovailabilitas vitamin D menurun (13). Rendahnya biovailabilitas vitamin D akan menggangu absorbsi kalsium. Asupan kalsium yang terganggu, akan memengaruhi pembentukan kekuatan tulang.

Artikel ini bertujuan untuk memberikan informasi mengenai hubungan antara vitamin D dan kalsium dengan obesitas, serta apakah obesitas secara langsung dapat meningkatkan risiko munculnya penyakit pada tulang akibat rendahnya absorpsi kalsium.

\section{TINJAUAN LITERATUR}

Penelusuran literatur dilakukan dengan menggunakan mesin pencari American Journal of Clinical Nutrition, PubMed, Google Scholar, Elsevier, dan Cambridge Core yang diperoleh sebanyak 42 jurnal. Untuk mengakses jurnal berbahasa Inggris 
melalui American Journal of Clinical Nutrition didapat 4 jurnal, PubMed 17 jurnal, Elsevier 6 jurnal, dan Cambridge Core 7 jurnal. Sedangkan untuk mengakses jurnal berbahasa Indonesia melalui Google Scholar didapat 8 jurnal. Kata kunci yang digunakan diantaranya obesitas dan vitamin D, obesitas dan kalsium, kalsium dan vitamin D. Jurnal yang ditelusuri harus yang diterbitkan dalam 10 tahun terakhir pada jurnal nasional maupun internasional dengan jumlah jurnal atau artikel yang di review berjumlah 15 . Setelah dilakukan mapping dan sintesa jurnal, didapatkan hasil bahwa 12 dari 15 jurnal menyatakan adanya hubungan signifikan antara kadar vitamin D dalam tubuh dengan IMT atau jaringan adiposa. Sedangkan 2 dari 3 jurnal terakhir menyatakan adanya hubungan yang lemah. Alur penelitian digambarkan sebagai berikut:

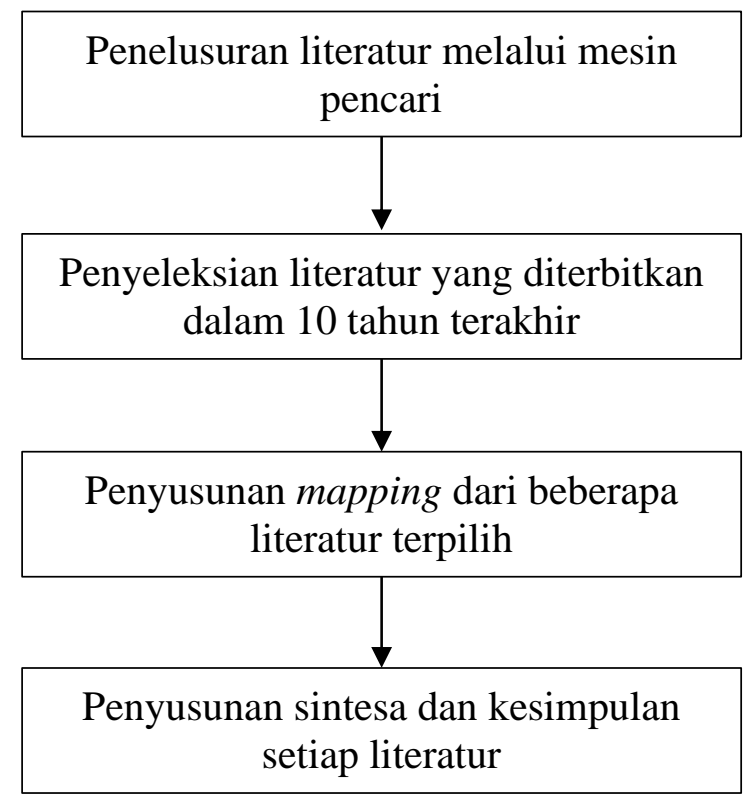

\section{Obesitas}

Obesitas berperan dalam meningkatkan morbiditas dan mortilitas (4). Kegemukan atau obesitas terjadi karena konsumsi makanan yang melebihi kebutuhan. Bila kelebihan ini terjadi dalam jangka waktu yang lama, dan tidak diimbangi dengan aktivitas yang cukup untuk membakar kelebihan energi, dalam jangka panjang kelebihan energi tersebut akan diubah menjadi lemak dan ditimbun di dalam jaringan adiposa di bawah kulit $(14,15)$. Aktivitas fisik yang kurang merupakan faktor yang paling berisiko menyebabkan obesitas $(4,8,16,17)$.

Secara fisiologis, obesitas didefinisikan sebagai suatu keadaan dengan akumulasi lemak yang berlebihan di jaringan adiposa (9). Pengklasifikasian obesitas mengguna-kan Indeks Massa Tubuh (IMT) yang dihitung dengan cara berat badan dalam kilogram dibagi tinggi badan dalam meter kuadrat. Menurut Kemenkes tahun 2018, pada klasifikasi nasional seseorang dinyatakan obesitas jika memiliki nilai IMT >25 (18).

\section{Vitamin D}

Vitamin D merupakan vitamin larut lemak yang dapat disintesis oleh tubuh dengan bantuan sinar matahari $(15,19)$. Sinar $U V-B$ matahari akan menyintesis vitamin $D$ menjadi bentuk aktif $\mathrm{D}_{3}$ (kolekalsiferol) $(13,20,21)$. Selain itu vitamin $D$ juga dapat diperoleh dari asupan makanan dalam bentuk vitamin $\mathrm{D}_{3}$ (kolekalsiferol) dan vitamin $\mathrm{D}_{2}$ (ergosterol) (22). Secara alami, vitamin $\mathrm{D}_{3}$ dapat ditemukan pada produk hewani, terutama pada minyak hati ikan $(13,19,22)$. Selain itu, vitamin D juga terdapat pada mentega, kuning telur, hati, salmon, susu, dan lain-lain $(13,15,23)$. Sedangkan vitamin $\mathrm{D}_{2}$ dapat ditemukan pada tumbuh-tumbuhan (22).

Didalam tubuh, bentuk vitamin D dari makanan akan diubah menjadi previtamin D (7-dehidrokolekalsiferol dan ergokalsiferol) dengan bantuan sinar matahari (24). Previtamin D akan diubah menjadi 25(OH)D didalam hati dan masuk 
kedalam ginjal untuk diubah menjadi bentuk aktif $1,25(\mathrm{OH})_{2} \mathrm{D}_{3}(19,21,25)$.

Kadar vitamin D yang adekuat berperan penting untuk perkembangan tulang sejak di dalam kandungan maupun pada saat masa anak-anak, dan juga untuk menjaga kesehatan tulang pada dewasa. Kelompok yang memiliki risiko tinggi terjadi kekurangan vitamin D diantaranya yaitu pada lansia, ibu hamil dan anak-anak $(19,21,24)$. Kadar vitamin D yang cukup dapat mempengaruhi produk kalsiumfosfat yang cukup juga, sehingga memungkinkan mineralisasi tulang yang efektif (26). Defisiensi vitamin D dengan kadar 25(OH) D <15 ng/mL menyebabkan disorganisasi kondrosit, hipertrofi, gangguan pada mineralisasi tulang, serta meyebabkan riketsia pada anak dan osteomalasia pada dewasa $(6,13,15,21)$. Selain itu, defisiensi vitamin D juga dapat meningkatkan risiko osteoporosis, penyakit jantung, serta diabetes mellitus tipe 2 (26).

Defisiensi vitamin D dapat terjadi akibat penurunan paparan sinar matahari, rendahnya asupan makanan sumber vitamin D $(10,23)$, dan tingginya kadar kolesterol $(21,26)$. Seseorang yang mengalami malnutrisi juga dapat mengalami risiko defisiensi vitamin D. Anak yang mengalami malnutrisi akan berisiko mengalami infeksi. Infeksi pada saluran pencernaan akan meningkatkan terjadinya diare dan muntah, sehingga penyerapan vitamin $\mathrm{D}$ akan terganggu yang akan menyebabkan rendahnya kadar vitamin D dalam tubuh (27).

\section{Kalsium}

Kalsium merupakan mineral yang paling banyak terdapat di dalam tubuh. Sekitar 99\% kalsium terdapat pada tulang dan gigi, sedangkan sisanya terdapat pada darah dan cairan ekstraseluler (13).
Meskipun hanya $1 \%$ kalsium berada dalam cairan ekstraseluler dan intraseluler, kalsium mempunyai fungsi yang sangat penting bagi tubuh (28). Selain berfungsi untuk pembentukan tulang dan gigi (15), kalsium dalam darah berperan untuk mempertahankan keseimbangan asam basa yang diatur oleh vitamin $\mathrm{D}$, hormon kalsitonin, dan PTH (Parathyroid Hormone) $(13,28,29)$. Selain itu, kalsium juga berperan untuk absorbsi vitamin $\mathrm{B}_{12}$, pengatur enzim pemecah lemak, lipase pankreas, ekskresi insulin oleh pankreas, serta pembentukan dan pemecahan asetilkolin (16).

Tulang tidak hanya berfungsi sebagai penopang tubuh, tetapi juga berperan untuk menjaga homeostasis kadar kalsium dalam plasma dan cairan ekstraseluler (9). Sumber asupan kalsium dapat diperoleh dari produk susu dan sayuran. Produk susu seperti susu, yoghurt, dan keju mengandung tinggi kalsium $(13,15)$. Selain dari produk olahan susu, kalsium juga dapat diperoleh dari sayuran (brokoli, bayam, wortel, kentang), dan juga buah-buahan (jeruk, stroberi, semangka, pisang) (30).

\section{Hubungan Kalsium dengan Vitamin D}

Vitamin D dibentuk di epidermis kulit dengan bantuan sinar matahari $(U V-B)$ yaitu vitamin $\mathrm{D}_{3}$ (7-dehidrokolesterol) dan akan mengalami dua kali hidrosilasi sebelum menjadi vitamin $\mathrm{D}$ aktif, yaitu $1,25(\mathrm{OH})_{2} \mathrm{D}$ atau kalsitriol $(21,31)$. Fungsi dari kalsitriol adalah meningkatkan kadar kalsium dan fosfat plasma. Vitamin D meningkatkan penyerapan kalsium di dalam usus untuk mempertahankan kadar kalsium dalam tubuh $(9,13,21,32)$.

Asupan kalsium dapat meningkatkan penggunaan 25(OH)D untuk proses metabolisme dalam tubuh (25). Tulang berfungsi sebagai tempat penyimpanan dan 
sumber kalsium ketika kalsium dalam darah menurun. Kadar kalsium dalam darah yang rendah dapat menstimulasi kelenjar paratiroid untuk membentuk PTH (Parathyroid Hormone). Kemudian, PTH akan mengaktivasi vitamin D agar dapat menstimulasi ginjal untuk mereabsorbsi kalsium sehingga semakin banyak kalsium yang diedarkan ke pembuluh darah $(21,25)$.

Penderita obesitas cenderung banyak berada di dalam ruangan akibat rendahnya tingkat aktivitas fisik yang menyebabkan jarangnya terkena sinar matahari sehingga dapat mempengaruhi kadar vitamin D dalam tubuh $(10,13)$. Apabila vitamin D yang diperoleh tubuh sedikit maka penyerapan kalsium akan kurang optimal (16).

\section{Hubungan Vitamin D dengan Obesitas}

Vitamin D dan kejadian obesitas mempunyai hubungan timbal balik (24). Rendahnya serum vitamin D dalam tubuh merupakan salah satu akibat dari obesitas (20). Hal ini disebabkan karena vitamin D larut dalam lemak dan mudah disimpan dalam jaringan adiposa (11). IMT (Indeks Massa Tubuh) dapat menjadi salah satu indikator atau dapat menggambarkan jaringan adiposa total seseorang. Selain IMT, metode lain untuk pengukuran lemak tubuh adalah dengan mengukur lingkar pinggang $(2,4)$.

Penderita obesitas memiliki kadar 25(OH)D yang lebih rendah dibandingkan dengan yang tidak obesitas (12,25). Rendahnya konsentrasi kadar 25(OH)D dalam tubuh dapat disebabkan oleh tingginya jaringan adiposa, peningkatan basal metabolik dan gaya hidup dari penderita obesitas yang cenderung kurang menyukai aktivitas di luar rumah serta kurangnya paparan sinar matahari $(10,13)$. Penyebab lain dari rendahnya kadar
25(OH)D serum pada penderita obesitas adalah kadar lemak yang tinggi menyebabkan bioavailabilitas vitamin D menurun dan kadar 25(OH)D serum terdeteksi rendah di dalam darah (27).

Ada dua teori yang menjelaskan penyebab rendahnya kadar vitamin $\mathrm{D}$ pada penderita obesitas yaitu teori sekuestrasi dan teori degradasi.

1. Teori Sekuestrasi: menyatakan bahwa penderita obesitas mengalami kegagalan dalam mengkonversi previtamin $\mathrm{D}$ menjadi vitamin $\mathrm{D}$ di jaringan kulitnya, karena tingginya jaringan adiposa yang dapat menyita vitamin yang larut lemak sehingga kadar serum $25(\mathrm{OH}) \mathrm{D}_{3}$ menjadi rendah (27,31).

2. Teori Degradasi: menyatakan bahwa tingginya jaringan adiposa akan merangsang infiltrasi dari sel-sel imun yang teraktivasi kemudian akan menyebabkan inflamasi dan penurunan (degradasi) vitamin D (27).

Keterkaitan vitamin D dengan obesitas memperlihatkan tidak hanya suatu kondisi penimbunan jaringan adiposa, tetapi juga peningkatan kadar leptin (12). Leptin melalui fibroblast growth faktor-23 (FGF-23), yaitu faktor fosfaturik yang berperan dalam metabolisme vitamin $\mathrm{D}$ di ginjal dapat menekan sintesis $1,25(\mathrm{OH})_{2} \mathrm{D}$, bentuk aktif vitamin $\mathrm{D}$ yang dibentuk di ginjal (11).

Selain itu, fungsi enzim untuk hidroksilasi yaitu 25-ohase dan 1- $\alpha$ hidroksilase akan menurun pada orang obesitas. Akibatnya, seorang yang mengalami obesitas setidaknya memerlukan dua kali lebih banyak vitamin D dibandingkan dengan seorang denghan berat badan normal untuk mempertahankan kadar serum 25(OH)D sebanyak 30-60 $\mathrm{ng} / \mathrm{mL}(20,25)$. 


\section{Hubungan Kalsium dengan Obesitas}

Konsumsi kalsium yang cukup dalam diet harian dapat menurunkan berat badan dan sintesis lemak (9). Seseorang yang mengonsumsi makanan yang mengandung tinggi kalsium (1200-1300 mg/hari) menunjukkan penurunan yang lebih besar pada lingkar pinggang dan rasio pinggang pinggul dibandingkan dengan subjek yang mengonsumsi makanan serupa dengan kandungan kalsium rendah $(<500 \mathrm{mg}$ kalsium/hari). Kalsium berperan dalam meningkatkan oksidasi lemak dan menurunkan lingkar pinggang (29).

Berdasarkan penelitian Zemel dkk (2010) menunjukkan bahwa asupan kalsium memiliki hubungan dengan obesitas (29). Asupan kalsium yang cukup dibutuhkan untuk mengurangi risiko terjadinya obesitas. Peran kalsium terdapat dalam pengaturan metabolisme energi; terutama kalsium intraseluler, yang berperan pada metabolisme lemak dan simpanan trigliserida. Jika asupan kalsium rendah akan terjadi penurunan kalsium plasma. Hal ini akan berakibat pada peningkatan kalsium intraseluler yang akan merangsang terjadinya lipogenesis di dalam jaringan adiposa dan jika dibiarkan akan menyebabkan obesitas sentral (33). Vitamin D juga dibutuhkan untuk membantu penyerapan kalsium, agar tidak terjadinya peningkatan kalsium intraseluler (16). 
Tabel 1. Hasil Penelitian dari Beberapa Sumber Terpilih

No. Sumber $\quad$ Subjek Kekuatan Hubungan $\quad$ Kesimpulan Topik

1. Alloubani et Laki-laki dan Peningkatan IMT serta rendahnya paparan sinar al., (2019) perempuan dewasa matahari, asupan vitamin D, dan kalsium akan berusia 18 - 60 tahun di Kota Tabuk, pantai barat laut Arab Saudi.

meningkatkan defisiensi vitamin $\mathrm{D}$ dengan nilai

OR masing-masing $3.2 ; 8.5 ; 9.7 ; 12.2$ dengan nilai $p>0.05$ (ada hubungan yang signifikan).

2. Grønborg et

al., (2015)

(34)

Laki-laki

dan

perempuan dewasa berusia $28-47$ tahun di Denmark.

3. Oktavia S.N. Siswa (2019) (11) Pembangunan

SMA Ada perbedaan yang signifikan dari tingkat di vitamin D rata-rata dalam darah siswa obesitas Padang, Sumatera dibanding siswa normal $(p=0,025)$.

Barat.

Ada perbedaan proporsi kejadian obesitas antara responden yang kekurangan vitamin D dibandingkan dengan mereka yang memiliki tingkat vitamin D cukup $(p=0,020)$.

4. Rosenblum et al., (2012)

(33)

Laki-laki

dan perempuan dewasa berusia 18 - 65 tahun di Amerika Serikat.

5. Walsh et al., (2016) (12)
Laki-laki dan

perempuan dewasa berusia 25 - 75 tahun memiliki kadar serum 25(OH)D yang lebih
- Hasil penelitian menunjukkan bahwa defisiensi vitamin D lebih tinggi terjadi pada perempuan dan seseorang yang berpendapatan tinggi.

- Faktor risiko defisiensi Vitamin D diantaranya merokok, rendahnya paparan sinar matahari, olahraga, redahnya asupan vitamin D dan kalsium, kenaikan IMT, kadar kolesterol, LDL, HDL dan gula darah puasa.

- Tidak ada efek lemak tubuh yang terlihat pada respons status vitamin D setelah suplementasi (10 atau $20 \mathrm{~g} / \mathrm{hari}$ ) atau plasebo.

- Tidak ada hubungan dasar antara persentase lemak tubuh dan status vitamin $\mathrm{D}$, dan persentase lemak tubuh tidak berpengaruh pada respons terhadap suplementasi vitamin $\mathrm{D}$.

- Vitamin D mempengaruhi konsentrasi Ca, bila kadar vitamin D rendah maka kadar $\mathrm{Ca}$ juga rendah yang akan merangsang ekspresi dan aktivitas fatty acid synthase (FAS). FAS merupakan enzim yang berperan dalam lipolisis. Rendahnya kadar vitamin D dalam membantu penyerapan $\mathrm{Ca}$ memicu kejadian obesitas.

- Tingginya jaringan adiposa membuat vitamin D menumpuk, sehingga vitamin D yang ada di peredaran darah hanya sedikit.

Pada orang dewasa yang kelebihan berat badan dan obesitas, penurunan sedang dalam asupan energi dan suplementasi kalsium dan vitamin D dalam minuman menyebabkan penurunan lemak intraabdominal.

Semakin tinggi IMT seseorang, semakin rendah kadar serum $25(\mathrm{OH}) \mathrm{D}$ dalam tubuh rendah dibandingkan dengan yang normal pada 
di South Yorkshire, Inggris. musim semi dengan nilai
hubungan yang signifikan).
6. Gallagher et

al., (2013)

(35)
Perempuan dewasa

usia 57 - 90 tahun di

Amerika Serikat.
7. Damayanti et al., (2017) (36)

8. Kim Hanseul et al., (2020) (37)

\section{Pasien}

kanker 65 tahun di RSUD Dr. Moewardi Surakarta.

Laki-laki

dan perempuan dewasa berusia 30 - 80 tahun di Boston,

Massachusetts,

Amerika Serikat.

9. Cheng et al. (2010) (38)

Laki-laki dewasa usia $\geq 35$ tahun dan perempuan usia $\geq 40$ tahun di Inggris.

10. Vimaleswara $n$ et al., (2013) (39)
Laki-laki perempuan Inggris, Finlandia, Kanada, dan Swedia. total hubungan terbalik yang signifikan antara $(p<0,0001)$
Terdapat hubungan yang lemah antara IMT Tidak ada hubungan signifikan antara IMT dan asupan vitamin D $(r=0,188 ; \quad p=0,266)$ dan asupan vitamin $\mathrm{D}$ $(r=0,113 ; p=0,507)$ dengan serum $25(\mathrm{OH}) \mathrm{D}$.

Terdapat hubungan yang signifikan antara kejadian obesitas dengan kadar serum $25(\mathrm{OH}) \mathrm{D}$ $(p<0,0001)$.

- Respon terhadap vitamin $\mathrm{D}$ tergantung pada berat badan.

- Perempuan dengan IMT $<25 \mathrm{~kg} / \mathrm{m}^{2}$ memiliki kadar $25(\mathrm{OH}) \mathrm{D}$ yang jauh lebih tinggi dibandingkan dengan yang memiliki IMT $>25 \mathrm{~kg} / \mathrm{m}^{2}$ setelah suplementasi vitamin D.

- Kelompok perempuan dengan IMT normal $\left(<25 \mathrm{~kg} / \mathrm{m}^{2}\right)$ menunjukkan respons terhadap vitamin D pada tingkat dosis apa pun dibandingkan dengan kelompok lainnya.

dengan serum $25(\mathrm{OH}) \mathrm{D}$, namun variabel usia menunjukkan hubungan yang bermakna $(p=0,046)$ dengan serum $25(\mathrm{OH}) \mathrm{D}$, dengan kekuatan hubungan yang tergolong cukup atau sedang $(r=0,335)$.

Kelebihan adipositas mengakibatkan resistensi vitamin D dalam menekan kadar PTH, bahkan ketika vitamin D diberikan dengan dosis tinggi.

Terdapat hubungan yang berbanding terbalik antara kadar 25(OH)D dengan SAT (subcutaneous adipose tissue) dan VAT (visceral adipose tissue) dengan nilai $p<0,0001$.

Semakin tinggi jaringan adiposa (terutama jaringan viseral) pada seseorang, semakin rendah kadar $25(\mathrm{OH}) \mathrm{D}$ pada tubuh. Prevalensi defisiensi vitamin $\mathrm{D}(25(\mathrm{OH}) \mathrm{D}<20 \mathrm{mg} / \mathrm{ml})$ tiga kali lipat lebih tinggi pada mereka yang memiliki SAT dan VAT yang tinggi dibandingkan dengan SAT dan VAT rendah dengan nilai $p<0,0001$.

BMI yang lebih tinggi mengarah ke status vitamin $\mathrm{D}$ atau kadar 25(OH)D yang lebih rendah, memberi bukti bahwa obesitas merupakan faktor risiko kausal untuk defisiensi vitamin D.
Terdapat hubungan antara kadar vitam Investigasi Genetik Sifat Antropometrik (GIANT) $(\mathrm{n}=123,864)$. Setiap kenaikan $1 \mathrm{~kg} / \mathrm{m}^{2}$ IMT dikaitkan dengan penurunan kadar $25(\mathrm{OH}) \mathrm{D} 1,15 \%$ lebih rendah $\left(p=6.52 \times 10^{-27}\right)$. 
11. Drincic et al.,

(2013) (40)

Laki-laki

perempuan

dan
berusia 19 - 68 tahun

di Omaha, Nebraska,

Amerika Serikat.

12. Kirsty et al., (2012) (41)

Dewasa muda usia 20 - 40 tahun dan lansia usia $\geq 64$ tahun Irlandia.

13. Didriksen et al., (2013)

(42)

14. Zhou et al., (2015) (43)

Perempuan dewasa di Norwegia.

Terdapat hubungan yang signifikan antara IMT dan suplementasi vitamin D dengan kadar $25(\mathrm{OH}) \mathrm{D}$ dengan nilai $p<0.001$.

Berat badan dan dosis suplementasi vitamin D secara langsung berhubungan dengan kadar 25(OH)D dan menyiratkan bahwa orang gemuk membutuhkan lebih banyak vitamin D3 daripada orang dengan berat badan normal untuk mencapai kadar yang sama.

Terdapat hubungan negatif antara IMT dengan kadar $25(\mathrm{OH}) \mathrm{D}$ pada lansia setelah suplementasi dengan nilai $p=0,026$.

\section{,}

Terdapat hubungan negatif antara kadar 25(OH)D dan IMT pada awal penelitian, yang kemudian menjadi signifikan secara statistik setelah 6 bulan dengan suplementasi vitamin D $(p<0,001)$.

Laki-laki dewasa usia Tidak ada perbedaan yang signifikan 18 - 69 tahun di China.

$(p>0,05)$ dalam kadar awal 25(OH)D antara kelompok obesitas dan berat badan normal Setelah suplementasi vitamin D, kadar 25(OH)D pada kelompok obesitas berubah menjadi signifikan $(p<0,05)$; namun, peningkatan kadar 25(OH)D pada kelompok obesitas masih lebih rendah jika dibandingkan dengan berat badan normal.

15. Nikolova et al., (2020)

(44)

Laki-laki

dan perempuan dewasa $\mathrm{d} i$ Bulgaria.
Status vitamin D berbanding terbalik dengan ukuran awal adipositas dan IMT juga berbanding terbalik dengan perubahan status vitamin D setelah suplementasi pada lansia ( $\geq 64$ tahun), tetapi tidak pada orang dewasa muda (20-40 tahun).

Respon kadar 25(OH)D terhadap suplementasi vitamin D bergantung pada genetik, kadar 25(OH)D awal, dan IMT.

Status awal vitamin D pada kelompok obesitas dan berat badan normal adalah serupa. Namun, suplementasi oral vitamin D menunjukkan penurunan bioavailabilitas vitamin D pada kelompok obesitas.

Ada hubungan tingkat vitamin D dengan indeks komposisi tubuh, tetapi hubungan ini umumnya sangat lemah. 


\section{SIMPULAN}

Secara keseluruhan, sejumlah besar penelitian membuktikan hubungan negatif antara IMT dan jaringan adiposa dengan kadar vitamin D. Rendahnya kadar vitamin D pada penderita obesitas kemungkinan besar disebabkan oleh rendahnya paparan sinar matahari, serta rendahnya asupan dan absorbsi vitamin D.

Jadi, obesitas memang secara langsung dapat mempengaruhi biovailabilitas vitamin D yang kemudian akan mengganggu absorbsi kalsium dalam tubuh. Namun penelitian lebih lanjut dan mendalam diperlukan untuk membuktikan bahwa penderita obesitas memiliki faktor risiko langsung terhadap penyakit tulang seperti osteomalasia, riketsia dan osteoporosis akibat rendahnya absorbsi kalsium dari pengaruh rendahnya kadar vitamin D dalam tubuh.

\section{UCAPAN TERIMA KASIH}

Terima kasih penulis sampaikan kepada semua pihak atas dukungannya dalam proses penyusunan artikel review ini.

\section{KONFLIK KEPENTINGAN}

Penulis menyatakan tidak memiliki konflik kepentingan dengan organisasi apa pun, yang dapat menimbulkan pertanyaan bias dalam diskusi dan kesimpulan naskah.

\section{REFERENSI}

1. Bhurosy T, Jeewon R. Overweight and Obesity Epidemic in Developing Countries: A Problem with Diet, Physical Activity, or Socioeconomic Status? Sci World J. 2014;2014.

2. World Health Organization (WHO). Obesity and Overweight [Internet]. 2021. Available from: https://www.who.int/newsroom/fact-sheets/detail/obesity-and- overweight

3. Kementerian Kesehatan RI Badan Penelitian dan Pengembangan. Hasil Utama Riset Kesehatan Dasar. Kementerian Kesehatan Republik Indonesia. 2018.

4. Kementerian Kesehatan RI. Epidemi Obesitas. Jurnal Kesehatan. 2018. p. 1-8.

5. Sahoo K, Sahoo B, Choudhury AK, Sofi NY, Kumar R, Bhadoria AS. Childhood Obesity: Causes and Consequences. J Fam Med Prim Care. 2015;4(2):187.

6. Paramita, Louisa M. Berbagai Manfaat Vitamin D. Cermin Dunia Kedokt. 2017;44(10):736-40.

7. Hou J, He C, He W, Yang M, Luo X, Li C. Obesity and Bone Health: A Complex Link. Front Cell Dev Biol. 2020;8(December):1-16.

8. WHO. Overweight and Obesity. WHO Global Strategy on Diet, Physical Activity and Health. 2003.

9. Dewajanti AM, Rumiati F, Pengajar S, Biokimia B, Fisiologi B. Tinjauan Pustaka Peran Kalsium dalam Penurunan Berat Badan pada Obesitas. 2017;

10. Savastano S, Barrea L, Savanelli MC, Nappi F, Di Somma C, Orio F, et al. Low vitamin D status and obesity: Role of nutritionist. Rev Endocr Metab Disord. 2017;18(2):215-25.

11. Oktavia SN. Hubungan Kadar Vitamin D Dalam Darah Dengan Kejadian Obesitas Pada Siswa Sma Pembangunan Padang. J Akad Baiturrahim Jambi. 2019;8(1):1.

12. Walsh JS, Evans AL, Bowles S, Naylor KE, Jones KS, Schoenmakers I, et al. Free 25hydroxyvitamin D is low in obesity, 
but there are no adverse associations with bone health. Am J Clin Nutr. 2016;103(6):1465-71.

13. Gandy JW, Madden A, Holdsworth M. Gizi \& Dietetika. Jakarta: EGC; 2014.

14. Silbernagl S, Lang F. Teks \& Atlas Berwarna Patofisiologi. Jakarta: EGC; 2017.

15. Hardinsyah, Supariasa. Ilmu Gizi Teori dan Aplikasi. Jakarta: EGC; 2016. 37 p.

16. Rosa S, Riamawati L. Hubungan Asupan Kalsium, Air, dan Aktivitas Fisik dengan Kejadian Obesitas Sentral pada Pekerja Bagian Perkantoran. J Amerta Nutr. 2019;3(1):33-9.

17. Suastika K. Update in The Management of Obesity. Acta Med Indones. 2006;38:231-7.

18. Kemenkes RI. Klasifikasi IMT. 2019.

19. Almatsier S. Prinsip Dasar Ilmu Gizi. Jakarta: Gramedia Pustaka Utama; 2016. 68 p.

20. Walsh JS, Bowles S, Evans AL. Vitamin D in obesity. Curr Opin Endocrinol Diabetes Obes. 2017;24(6):389-94.

21. Rodwell VW, Bender DA, Botham KM, Kennelly PJ, Weil PA. Harper's Illustrated Biochemistry. 30th ed. Jakarta: EGC; 2018. 573;584-585.

22. Gil Á, Plaza-Diaz J, Mesa MD. Vitamin D: Classic and Novel Actions. Ann Nutr Metab. 2018;72(2):87-95.

23. Zhao G, Ford ES, Tsai J, Li C, Croft JB. Factors Associated with Vitamin D Deficiency and Inadequacy among Women of Childbearing Age in the United States. ISRN Obstet Gynecol. 2012;2012:1-9.
24. Pannu PK, Calton EK, Soares MJ. Calcium and Vitamin D in Obesity and Related Chronic Disease. 1st ed. Vol. 77, Advances in Food and Nutrition Research. Elsevier Inc.; 2016. 57-100 p.

25. Ummah WN. Hubungan Antara Asupan Kalsium, Lingkar Pinggang dan Kadar Vitamin D Pada Remaja. Proposal Penelitian. 2016.

26. Alloubani A, Akhu-Zaheya L, Samara R, Abdulhafiz I, Saleh A, Altowijri A. Relationship between Vitamin D Deficiency, Diabetes, and Obesity. Diabetes Metab Syndr Clin Res Rev. 2019;13(2):1457-61.

27. Sundari LPR. Defisiensi Vitamin D Pada Obesitas. Sport Fit J. 2018;6(1):1-5.

28. $\mathrm{Pu} \mathrm{F}$, Chen N, Xue S. Calcium Intake, Calcium Homeostasis and Health. Food Sci Hum Wellness. 2016;5(1):8-16.

29. Song Q, Sergeev IN. Calcium and vitamin D in obesity. Nutr Res Rev. 2012;25(1):130-41.

30. Mahan LK, Raymond JL. Krause's Food \& The Nutrition Process. Elsevier; 2017. 56068 p.

31. Pourshahidi LK. Vitamin D and obesity: Current perspectives and future directions. Proc Nutr Soc. 2015;74(2):115-24.

32. Çaykara B, Öztürk G, Mutlu HH, Arslan E. Relationship Between Vitamin D, Calcium, and Phosphorus Levels. J Acad Res Med. 2020;10(3):252-7.

33. Rosenblum JL, Castro VM, Moore CE, Kaplan LM. Calcium and vitamin D supplementation is associated with decreased abdominal visceral adipose tissue in overweight and obese adults. Am J Clin Nutr. 
2012;95(1):101-8.

34. Grønborg IM, Lundby IM, Mølgaard C, Jakobsen J, Ovesen L, Andersen

R. Association of Body Fat and Vitamin D Status and The Effect of Body Fat on The Response to Vitamin D Supplementation in Pakistani Immigrants in Denmark. Eur J Clin Nutr. 2015;69(3):405-7.

35. Gallagher JC, Yalamanchili V, Smith LM. The Effect of Vitamin D Supplementation on Serum 25OHD in Thin and Obese Women. J Steroid Biochem Mol Biol. 2013;136(1):195-200.

36. Damayanti AY, Indarto D, Wasita B, Ardyanto TD. Indeks Massa Tubuh, Asupan Vitamin D, dan Serum 25Hydroxyvitamin D pada Pasien Kanker Payudara. J Gizi Klin Indones. 2017;14(2):56.

37. Kim H, Chandler P, Ng K, Manson JAE, Giovannucci E. Obesity and Efficacy of Vitamin D3 Supplementation in Healthy Black Adults. Cancer Causes Control. 2020;31(4):303-7.

38. Cheng S, Massaro JM, Fox CS, Larson MG, Keyes MJ, McCabe EL, et al. Adiposity, Cardiometabolic Risk, and Vitamin D Status: The Framingham Heart Study. Diabetes. 2010;59(1):242-8.

39. Vimaleswaran KS, Berry DJ, Lu C, Tikkanen E, Pilz S, Hiraki LT, et al. Causal Relationship between Obesity and Vitamin D Status: BiDirectional Mendelian Randomization Analysis of Multiple
Cohorts. PLoS Med. 2013;10(2).

40. Drincic A, Fuller E, Heaney RP, Armas LAG. 25-Hydroxyvitamin D Response to Graded Vitamin D3 Supplementation Among Obese Adults. J Clin Endocrinol Metab. 2013;98(12):4845-51.

41. Kirsty Forsythe L, Livingstone MBE, Barnes MS, Horigan G, McSorley EM, Bonham MP, et al. Effect of Adiposity on Vitamin D Status and The 25Hydroxycholecalciferol Response to Supplementation in Healthy Young and Older Irish Adults. Br J Nutr. 2012;107(1):126-34.

42. Didriksen A, Grimnes G, Hutchinson MS, Kjrergaard M, Svartberg J, Joakimsen RM, et al. The Serum 25-Hydroxyvitamin D Response to Vitamin D Supplementation is Related to Genetic Factors, BMI, and Baseline Levels. Eur J Endocrinol. 2013;169(5):559-67.

43. Zhou JC, Zhu YM, Chen Z, Mo JL, Xie FZ, Wen YH, et al. Oral Vitamin D Supplementation Has a Lower Bioavailability and Reduces Hypersecretion of Parathyroid Hormone and Insulin Resistance in Obese Chinese Males. Public Health Nutr. 2015;18(12):2211-9.

44. Nikolova M, Penkov A. Serum Levels of $25(\mathrm{OH})$ Vitamin D in Adults with Obesity Sarcopenia. Proc Nutr Soc. 2020;79(OCE2):2022. 